\title{
Role of Lead Bank in Poverty Alleviation
}

\author{
Suman Kumari* \\ Student, Department of Economics, Magadh University, Patna, India \\ *Corresponding author: suman137720@yahoo.co.in
}

\begin{abstract}
This paper presents an overview on the role of lead bank in poverty alleviation.
\end{abstract}

Keywords: Branch expansion, Branch network, Financial institution, Lead bank.

\section{Introduction}

Lead Bank has pivotal role in poverty alleviation in as much as government policies are being implemented at grass root level by these banks. Branch expansion in rural areas emphasise loan distribution to needy farmers, artisans, skilled persons for job creation and subsequent contribution in poverty alleviation of the masses.

Table 1

SBI as Lead Bank in the Country spread over 7 States

\begin{tabular}{|c|c|c|}
\hline Name of the state & No. Lead District & Name of District \\
\hline \multirow[t]{9}{*}{ Assam } & 9 & Darang \\
\hline & & Kamrup \\
\hline & & Goalpara \\
\hline & & Sonitpur \\
\hline & & Barpeta \\
\hline & & Dhubri \\
\hline & & Kokrajhar \\
\hline & & Pragjyotispur \\
\hline & & Jorhat \\
\hline \multirow[t]{6}{*}{ Bihar } & 6 & Bhagalpur \\
\hline & & Banka \\
\hline & & Munger \\
\hline & & Dumka \\
\hline & & Begusarai \\
\hline & & Khagaria \\
\hline \multirow[t]{4}{*}{ West Bengal } & 4 & Virbhum \\
\hline & & Burdaman \\
\hline & & Hoogly \\
\hline & & Howrah \\
\hline \multirow[t]{4}{*}{ Orissa } & 4 & Baleshwar \\
\hline & & Cuttack \\
\hline & & Puri \\
\hline & & Tekanal \\
\hline \multirow[t]{3}{*}{ Rajasthan } & 3 & Jaipur \\
\hline & & Jodhpur \\
\hline & & Nagaur \\
\hline \multirow[t]{3}{*}{ Punjab } & 3 & Ropar \\
\hline & & Ludhiana \\
\hline & & Jullandhar \\
\hline \multirow[t]{4}{*}{ Himachal Pradesh } & 4 & Simla \\
\hline & & Sirmur \\
\hline & & Solan \\
\hline & & Bilaspur \\
\hline
\end{tabular}

Overall banking activities of State Bank emphasises that SBI has maintained its social obligations during post-nationalisation period. The main approach of the analysis of this topic is to highlight programme for branch expansion, which has been in the root of change of the banking system in our country. The overall analysis of this topic has been divided into following four parts, part first reviews the literature on the promotion of banking habits. Part second had bank and branch expansion, part third presents the branch expansion in Sahibganj district and lastly part fourth conclude with a note on the impact of growth of bank branches on deposits mobilisation and deployment of credit.

\section{Promotion of Banking Habits}

We propose to deal with the conceptual concept and aspects of the promotion of the banking habits and economic development. It is the development of banking habit which influences the banking business and it is the branch expansion which is responsible for growth and development of banking habit

Development involves finance as well as goods-Gusley \& Shaw [1].

Real growth cannot be bought with money alone [2].

Bank make almost no direct addition to national output, and the product of the banks, the actual and imputed deposits and checking services, are surely of low priority as consumer goods in nations impoverished of food and clothing. Of course the concern of the developing economic for the growth of their banking system is not premised on any such narrow conception of the contribution of banks. What is recognised as relevant is the indirect contribution to the growth of real variables which a growth in monetary variable can make exactly what the connection is between these two sets of variables is not always so clearly recognised

The visible correlation in the world are indeed commending whether one relates the development of the nation's financial system to its per capita income across countries at a moment of time or across time for a particular country, the relationship between real and monetary variables is undeniable. Furthermore, economist- from Adam Smith on have frequent advocated this relationship with the fact that financial institutions develop and size and complexity of the financial system increases as economic growth proceeds, 
There can be no quarrel [3]. It is equally certain that the simultaneous growth of the real and financial parts of the economy is no independent coincidental phenomenon but that each reinforces and fosters the other.

Nevertheless, there is in all this no clear mandate for making all leading sector of banking. When the Central Bank artificially encourages and fosters the spread of bank offices, however, it is not just permitting the simultaneous growth of the real and financial parts of the economy. Such policies rest on the belief that the development of the "banking habit" may precede and itself promote the real growth of the economy. The observed co-relations in the world and the writings of economists have nothing to say about this belief. Indeed, the few economists who have proposed a clear direction of causation between real and financial growth usually suggest the opposite. "By and large, it seems to be the case that where enterprise leads finance follows" [4]. Societies in which other conditions (for growth) were favourable were usually capable of devising adequate financial institutions [5]. Even W.W. Rostow, despite his conclusion that "as a pre-condition, it appears necessary that institutions be developed which provide cheap and adequate working capital 'notes' the demand side of the investment process rather than the supply of loanable funds may be decisive elements in take-off" [6].

While it is very unlikely that the size of the banking system from society's view point at any time will be exactly that which private profit opportunities encourage bankers to create, this fact in itself does not indicate whether the Central bank should interfere in the direction of a larger or smaller number of bank offices.

"It is one thing for a central banking to promote the establishment of new financial institutions to supervise and examine them, to help them develop efficiency and trustworthiness It is quite another to place on the central bank heavy continuing responsibility for financing these institutions. And this is the situation in country after country [7].

The case for a prior, or leading, expansion of the banking system can be based and to display some of the problems connected with each of these grounds. The conclusions which can be reached from such an analysis are fundamentally two-

1. A case can be made for pushing the growth of the banking system ahead of the real growth of the economy but it is far from indisputable, and

2. For a policy of rapid bank office expansion to be beneficial or other concomitant changes must be made in the structure and conduct of the financial system.

The existence of a greater number of bank offices may evoke a greater volume of real saving. For this to happen it is of course not enough that the new bank offices mobilise more successfully those funds that represent savings that would have occurred any way, it is necessary that the total abstention from consumption be increased. This result may follow from the mere existence of new savings institutions. There is a widespread belief that saving is "institution-elastic" for example, Lewis claims that" Experience shows that the amount of savings depends partly on how wide spread these facilities (i.e. savings institutions) are, if they are pushed right under the individual's nose..... people save more than if the nearest savings institution is some distance away [8].

Potter says, "The possible determinants of such an 'elasticity' are basically three [9];

1. The existence of accessible banks may mean that for the first time, individual saving can take place without the need for a concomitant act of investment either fixed investment or accumulation of stocks of goods. The process of saving therebyfreed from problem of investment opportunity.

2. Closely related is the possibility that bank deposits represent a new form of saving with less riskness \& greater liquidity.

3. In a stagnant rural economy, where saving previously earned a low or even negative yield, the interests on bank deposits may attract saving.

The case, while, is not indisputable. Almost every desirable attributes of deposits applies equally to currency and the greater use of currency develops much more tenuously if at all from an extension of commercial bank offices or branches. Currency and deposits differ only in the kinds of risk each disposes upon its owner. Currency is more liable to loss or theft but deposits depends upon the solvency and liquidity of the intermediary with which they are held. It is not at all certain that the sudden availability of deposit assets in an area where currency is already used provides a stimulus to saving.

Even where deposits prove to be new, different and less risky technique of accumulating assets, it does not necessarily follow that saving will be increased. The usual reasoning that consumption of goods with risk attached in this case saving would be linger in the absence of that risk, neglects that uncertainty counterparts of the "Sargent man". ${ }^{10}$ Some people may wish to be certain of having saved a given amount for the future, just as they must save more at lower interest rates, so also must they save more if, the probability is less than unity that any given saving will survive until it is needed For such people the enhanced likelihood of "survival" offered by currency or deposit may permit a reduction in savings.

The assumption that deposits are a more desirable form of saving in itself open to question. Aside from excessive worry about the safety of deposit, there is often a very justified fear that inflation will reduce the value of the accumulated savings. Under such circumstances the alternative of holding such assets as food grains, good or land may be definitely less risky.

Finally, questions arise concerning the higher interest rates on bank deposits, barely do demand deposits earn interest in any country and the rates paid on savings and time deposits in underdeveloped countries are seldom over 3 per cent. However, the more relevant real rate of interest is always somewhat lower even where the secular rate of price increases has been small as it has over most of Asia and Africa. The interest elasticity of 
saving must also be considered of dubious sign in theory and usually in-significant in the empirical hundies of developed economies there is no reason for expecting a large positive interest elasticity of saving in underdeveloped economies.

These qualifications should underline the frequent warning of economists "against assuming that a mere multiplication of saving institutions will in itself solve the problem of inadequate savings" [11].

Nevertheless, it would be equally an error to overlook completely the possibilities that real savings can be increased in this manner. What is really surprising is not how frequently the official rational for promoting of bank office expansion refers to these powerful possibilities that bank branch expansion will stimulate private saving. Perhaps this apparent reluctance on the part of central bank to emphasize the saving creative ability of the banking system follows from a recognition of its expensiveness to society. Even if banks do "cause" new savings, the resource cost of bank branch expansion may be greater than the resources captured through new savings. Emphasis on the ability of new bank to create new savings also draw the two questions-

a) Are there no lower cost saving institutions than bank offices? And

b) Is private "transferred "saving really that important in the development process?

There is finally the larger question to what extent a ceteris paribus increase in savings contributes to growth. Although few would subscribe completely to Kaldor's belief that "it is lack of economic progress which keeps the savings coefficient low, rather than the other way round" [12]. There is currently a strong reaction among economists against the savings oriented approach to development. And yet it is entirely upon this approach that this aspect of the case for bank expansion rests.

In each of the principal areas where an extension of bank offices can influence the saving investment nexus, the above discussion suggests that the other changes need to be made together with enlargement of banking system. With respect to the quantity of saving a simplification of deposit procedures and maintenance of attractive interest yields may be needed. With respect to investment allocation, changes in bank loan policies may be an essential concomitant to expansion, indeed perhaps even more effort should be expanded on enlarging the scope of bank operations than an increasing the size.

Thus, in the background of the above analysis of the "promotion of the banking habit" seems to be useful in the case of the Indian economic scene. Although various if and buts are there, but while chalking out the programme of rural development, it is an essential precondition to have broad based network of banking system. Because any underdeveloped stagnant economy needs a heavy dose of investment for changing its stagnant character as development economists have advocated. And this may be brought about by changing the character of banking system as it is the cheap means of mobilisation of deposits and channeling them to the desired area of investment. Banking in India developed its business in the urban segment of the society and the major portion of the economy was completely out of the purview of the banking network and money and credit market was scattered fragmented. This very character of the Indian banking system leads to its nationalisation and the very scheme of Lead Bank was imposed on the commercial banks by the Reserve Bank of India. During post nationalisation period, there has been rapid growth of bank branches in the country. How far this rapid expansion of bank branches has influenced the asset creation process is being discussed in the next section in the context of the Sahibganj district which is one of the backward district of the country.

\section{Lead Bank and Branch Expansion}

The lead bank scheme was initiated by the Reserve Bank of India towards the end of 1969. All the districts in the country besides the metropolitan areas, were placed under the responsibility of one major bank. The lead bank which was entrusted with the onerous task of undertaking the survey of the area, depicting deposit and growth potential of the district and inducing other institutions to get established there. The rationale behind the lead bank scheme has been sufficiently summed up by the governor of the Reserve Bank of India in these words. "The scheme is a new experiment; its potentiality is greater and it is aimed at helping the banking system to achieve development at the grassroot level. Itmarks a step towards coordinated functioning of the banking system even while they remain in competition with each other" [13]. The extension and thrust of lead bank scheme has also been devoid of uniformity. The banking commission pointed out that "extension remain of banking facilities in a coordinated manner is certainly an important point of the infrastructure needed for development of an area in combination with other infrastructural facilities like transport, communication, storage, processing and marketing and so on and can make a significant difference to the economic life of an area, where such facilities have not been provided for the lead banks can have only limited success" [14].

Till February 1971, 8 out of 11 bank offices were located in Sahibganj district town. Sahibganj town alone contributed 92 per cent of the total deposits. The average population per bank branch was $1,48,735$ persons considerably large as compared to the all India average population of 52,000 persons per branch office. The Lead Bank Survey Report of the Sahibganj District which was undertaken in 1970-71 suggested seven growth centres for opening of branches in the first instance The remaining unbanked block headquarters of key village centre where necessary infrastructure is available, should be covered in the second phase of branch expansion programme

The following were the seven growth centres [15],

1. Sahibganj

2. Rajmahal

3. Borio 
4. Barhait

5. Barharwa

6. Taljhari

7. Pathna

Follow-up action of Lead Bank Report:

Since 1969-70, i.e., the publication of the Lead Bank Survey Report, there has been some progresses in the directions of branch expansion, deposit accretion and credit disbursement.

Trend in Branch Expansion:

A close look at the history of the commercial banking in India clearly reveals that till mid 1950's, it had an urban bias. This is born out by the fact that even the Imperial Bank of India, the largest banking company of the country was not ready to open 274 branches over a period of 5 years as suggested by the Rural Banking Enquiry Committee of 1950. With a lot of reluctance, the Imperial Bank of India agreed to open 114 branches over a period of five years. This symbolised the apathy of commercial banks in opening branches in rural areas [16].

It was only after the setting up of the SBI by taking over the Imperial Bank of India in July 1955 that a new input was given to taking banks to unbanked areas. This policy of balanced dispersal of commercial bank branches was also greatly facilitated by the branch licensing policy adopted by the RBI with greater thrust on rural branches expansion. However, the progress achieved until 1967 in respect of branch expansion was found to be rather tardy. As a result, the government sought to give further momentum to the process of bringing about better alignment between banking policy and general economic policy. This new thinking found concrete expression in the form of social control over banks. The subsequent nationalisation of 14 major Indian schedule commercial banks on 19 July 1969 paved the way for better regional distribution of bank branches. Besides, the instance by the RBI in the terms of its branch licensing powers that opening of four rural branches by a commercial bank would make it eligible to open branch at an urban or metropolitan centre also contributed significantly for the opening of bank branches in rural areas. Moreover, the Lead Bank Scheme entrusted the responsibility of identifying the places for opening of branches to the concerned Lead Bank in each district on the basis of surveys conducted by it. This has also facilitated the process of branch expansion in rural areas.

It is also pertinent to note that Regional Rural Bank have been specifically set up to cater to the requirement of rural sector and since they have been sponsored by leading commercial banks they may be regarded as rural components of commercial banks. This organisational innovation has helped overcoming whatever obstacles the state Banks had in reaching out rural pockets of the country.

As could be seen from the table, there has been a spectacular increase in the number of branches of state banks in the post nationalisation period. Rural Branches numbering 1,832 at the end of June 1969 accounted for 22.4 per cent of total number of State Bank branches. However, their number has increased to 25, 446 as at the end of June 1962 accounting for 57.5 per cent of the total bank branches in the country.

Further, a close scrutiny of the trends would indicate that in the period immediately after the nationalisation, there was a big push in the rural branch expansion as evidenced by the fact that in the period between June 1969 and June 1974, the number of rural branches have been increased from 1,832 to 6,165 there by showing a rise of 336.5 per cent. But in the next quirquennium it registered an increase of only 248.5 per cent. It is clear that in the wake of social control and nationalisation measures there was a big leap in the setting up of rural branches by SBI.

It is clear that Sahibganj District is pretty backward in respect of selected major variables of banking development whereas average population per bank branch between July 1989 and Dec 1975 has been brought down from 2,06,000 to 64,000 in Bihar, it continued to be one lakh per branch for Sahibganj District. At the end of 1974, there were 755 branches in operation in Bihar, out of which the share of Sahibganj district where 21 only. In percentage terms, it came to 2.8. It explains that Sahibganj was underdeveloped from the point of view of banking even in comparison with other districts of Bihar.

Branch Network of State Bank:

One of the motives behind nationalisation lay in filling up unbanked and underbanked centres with banking offices and correcting the lopsided development of existing banking facilities. Prior to nationalisation, the banking structure in the country suffered from three-fold inadequacy,

a) A large part of the country was outside the ambit of State Banking sphere;

b) A large number of people were not covered by it, and

c) A large section of the economy was not served by its lending operations.

Nationalisation brought in its train a new seal to pierce the smoke- screen of large area and bigger- men in respect of bank location, operations and totum neglected sectors of yesterday into priority sectors of today. The district of Sahibganj has not been immune for this seal, though the progress has been slow, halting and erratic.

Prior to July 1969, only seven (7) branches were operating in the District of Sahibganj and all the seven centres were located in urban areas. It heavy concentration would be evident from the fact that six out of seven branches were located in only one block out of twenty-one blocks, namely, Borio and branch of State Bank of India was located in the sub divisional town of Sahibganj The following table gives details of it.

This scheme of banking development in the district of Sahibganj changed completely after 1969 nationalisation. When only seven branches could come up in four decades during pre-nationalisation days, 14 branches came to be established within half a decade after nationalisation. This growth rate of branch expansion, judged in historical perspective, is certainly creditable.

Still more creditable has been a change in the character of 
branches- a complete break with the past. Since 1970, out of the 14 new branches, 3 were located in rural centres and 6 were located in semi-urban centres. Thus, the majority of centres continued to be concentrated in urban areas, the impact of nationalisation on branch expansion was also discernible. The centre-wise break up of commercial banks have been given in the table 3 .

Table 2

Banking growth in Sahibganj district prior to nationalisation

\begin{tabular}{|c|l|c|c|}
\hline S. No. & \multicolumn{1}{|c|}{ Particulars } & Year & $\begin{array}{c}\text { Whether Urban/ } \\
\text { Semi Urban/Rural }\end{array}$ \\
\hline 1 & State Bank of India & 1927 & Urban \\
\hline 2 & Central Bank of India & 1943 & Urban \\
\hline 3 & Hindustan Commercial Bank & 1945 & Urban \\
\hline 4 & Punjab National Bank & 1951 & Urban \\
\hline 5 & Allahabad Bank & 1953 & Urban \\
\hline 6 & United Commercial Bank & 1964 & Urban \\
\hline 7 & State Bank of India & 1966 & Urban \\
\hline
\end{tabular}

Regional Study, Report, Table No. 4.7

Table 3

Centrewise break up

\begin{tabular}{|l|l|l|}
\hline S. No. & Centres & No. of Branches \\
\hline 1 & Rural & 3 \\
\hline 2 & Semi-Urban & 6 \\
\hline 3 & Urban & 12 \\
\hline
\end{tabular}

In addition to these branches four pay offices were also operating at the end of 1974 . The pay offices were located at urban areas of Sahibganj district.

Despite impressive progress which the banks have made in the district during the short span of time after nationalisation (1969-1974) there is a grant be way to be made up by the banking structure of this district even after a rapid branch expansion. Branch expansion contributes reach to all strata of society to disburse loans to needy persons, creation of job opportunities and thereby poverty alleviation through various schemes of the Government.

\section{Conclusion}

This paper presented an overview on role of lead bank in poverty alleviation.

\section{References}

[1] Gurley and Shaw (1955), "Financial Aspect of Economic Development", AER, Vol. XLV, (Sep).

[2] Chandler, LV. (1962), Central Banking and Economic Development Bombay University Press.

[3] Gurley and Shaw (1955) and Gold Smith (1955).

[4] Robinson (1952) "The generalization of the general theory" in the Range of interest and other essays, (London, Macmillan), P.86

[5] Habakkuk (HJ) (1954), "The Historical Experience on the Basic Conditions of Economic Progress" Indian Economic Journal

[6] Rostow, W.W (1960), PP.48-49.

[7] Chandler (1962), P. 7.

[8] Lewis, WA. (1965), The Theory of Economic Growth

[9] Porter, "Money and Monetary Policy to LDCS"

[10] Roberton DH. (1951), "Some Noten on the Theory of interests" in Money Trade and Economic Growth Essays Honour of Williams Macmillan).

[11] Bloomfield J. (1956). "Monetary Policy in underdeveloped Countries, Public Policy, Vol. 8.

[12] Küldor's (1960), "Characteristic of Economic Development" Essays on Economic Stability and growth London, Duckworth.

[13] S. Jagannathan address to Bengal Chamber of Commerce, Reserve Bank of India Bulletin, November, 1970.

[14] Report of the Banking Commission, P. 84.

[15] Sharma, R.D., Farm Financing by Commercial Bank.

[16] Saxena, C.N. "Commercial Bank in Current Development Strategy in India" SLN Sinha (ed). Reform of the Indian banking system, 1973, P. 129. 